\title{
Analisis Kelengkapan RPP Matematika pada Guru SMAN 5 Tapung
}

\author{
Tomy Abdullah' ${ }^{*}$, Maimunah ${ }^{2}$, Yenita Roza $^{3}$ \\ Pendidikan Matematika, Universitas Riau \\ Kampus Bina Widya KM. 12.5, Pekabaru, Riau, Indonesia \\ 1*tomy.abdullah7957@grad.unri.ac.id; ${ }^{2}$ maimunah@lecturer.unri.ac.id; \\ 3yenita.roza@lecturer.unri.ac.id
}

Artikel diterima: 19-01-2021, direvisi: 22-09-2021, diterbitkan: 30-09-2021

\begin{abstract}
Abstrak
Penelitian ini dilatarbelakangi masih adanya guru yang menjadikan RPP hanya sebagai syarat administrasi tanpa memperhatikan tentang kelengkapan RPP yang sesuai dengan Permendikbud 103 tahun 2014. Penelitian ditujukan untuk mendeskripsikan kesesuaian kelengkapan 3 RPP dari 3 guru matematika yang menggunakan Kurikulum 2013 pada SMA 5 Tapung. Penelitian ini menggunakan metode deskriptif kualitatif, sasaran penelitian ini adalah 3 RPP dengan materi Nilai Mutlak. Hasil dari analisis data menggunakan metode deskriptif kualitatif memberikan hasil dengan rata-rata $77,2 \%$ termasuk dalam kategori sesuai dengan Kurikulum 2013. Berdasarkan rata-rata yang diperoleh maka dapat dikatakan bahwa guru matematika di SMA 5 Tapung telah sadar dan sangat memperhatikan tentang aturan Permendikbud 103 tahun 2014.

Kata Kunci: kurikulum 2013, nilai mutlak, RPP.
\end{abstract}

\section{Analysis of the Completeness of RPP Components for Mathematics Teachers of SMAN 5 Tapung}

\section{Abstract}

The background of this research is that there are still teachers who make RPP only as an administrative requirement without paying attention to the completeness of the RPP following Permendikbud 103 of 2014. The research is aimed at describing the suitability of the completeness of 3 RPP from 3 mathematics teachers who use the 2013 Curriculum at SMA 5 Tapung. This study uses a qualitative descriptive method, the target of this research is 3 lesson plans with Absolute Value material. The results of data analysis using descriptive qualitative methods gave results with an average of $77.2 \%$ included in the category according to the 2013 Curriculum. Based on the average obtained, it can be said that the mathematics teacher at SMA 5 Tapung has been aware and very concerned about the rules of Permendikbud 103 of 2014.

Keywords: curriculum 2013, absolute value, RPP. 


\section{Pendahuluan}

Guru adalah salah satu faktor utama dalam dunia pendidikan, guru di Indonesia lazimnya dibentuk oleh Lembaga Pendidik Tenaga Kependidikan atau yang biasa disingkat LPTK (Yuniawatika, dkk., 2016). LPTK adalah perguruan tinggi yang diberi tugas oleh Pemerintah untuk menyelenggarakan program pengadaan guru pada pendidikan anak usia dini jalur pendidikan formal, pendidikan dasar, dan/ atau pendidikan menengah, serta untuk menyelenggarakan dan mengembangkan ilmu kependidikan dan non kependidikan (UU Nomor 87, 2013) . Hal ini mengindikasikan bahwa LPTK yang merupakan lembaga penghasil tenaga pendidik (guru) di Indonesia, sangat berperan bagi peningkatan kualitas sumber daya manusia di Indonesia (Budihardjo, 2012).

Guru sangat berperan penting dalam proses mengarahkan siswa agar berhasil dalam kegiatan pembelajaran (Sumartini, dkk., 2020). Guru memiliki peranan penting dalam menyajikan pembelajaran untuk memfasilitasi tercapainya tujuan pembelajaran yang akan dicapai serta memfasilitasi siswa mencapai kemampuan matematisnya (Nuraeni \& Luritawaty, 2017). Karena keberhasilan pendidikan sangat dipengaruhi oleh keefektifan guru dalam mengelola lingkungan belajarnya (Afriansyah, 2017). Keberhasilan siswa dalam proses pembelajaran dapat diamati dan diukur dari keberhasilan siswa dalam menyelesaikan beberapa tes, baik tes "formatif", tes "sumatif" dan tes keterampilan dengan mencapai tingkat keberhasilan dengan rata-rata 60\%, selanjutnya keberhasilan siswa tersebut dihubungkan dengan kompetensi dasar yang ditetapkan oleh kurikulum dengan tingkat ketercapaian yang ideal adalah $75 \%$, yang terakhir keterampilan vokasional atau praktek yang bergantung pada tingkat kesulitan dan resiko dengan rata-rata ketercapaian yang ideal adalah 75\%. Untuk mencapai semua hal tersebut guru dituntut semakain baik dalam proses mengajar dengan selalu upgrade kemampuan. Guru dalam tugasnya juga harus mampu menjadikan proses belajar mengajar menjadi keadaan yang nyaman dimana siswa tidak merasa tertekan dan mudah menyerap materi pembelajaran sehingga tugas guru tidak hanya sebagai pemberi materi tetapi juga berperan sebagai seorang motivator agar siswa semangat dalam belajar (Afriansyah, dkk., 2021). Nuraeni (2019) mengatakan dalam pendidikan ada tiga hal yang harus dikuasai oleh seorang guru, yaitu proses pembelajaran, kurikulum, dan sistem penilaian.

Guru yang bisa menjalankan semua tugas pokoknya dengan baik sebagai seorang pendidik dapat dikatakan sebagai guru profesional dengan kemampuan yang meliputi, merencanakan, menjalankan, dan mengevaluasi hasil pembelajaran (Rahayu, 2016; Tarusu, 2018). Sesuai dengan Permen No 22 Tahun 2016 mengenai Standar Proses dalam 
lampirannya menjelaskan tentang tugas wajib seorang pendidik adalah mempersiapkan rancangan rencana pembelajaran yang dibuat dalam bentuk Silabus dan Rencana Pelaksanaan Pembelajaran (RPP) mengacu pada Standar Isi yang mana sebelum memulai proses mengajar, guru seharusnya sudah menyusun perencanaan atau perangkat pembelajaran (Kunandar, 2014).

Sebagai seorang pendidik yang baik guru selalu diwajibkan mampu dalam menyusun RPP dan perangkat pembelajaran yang lengkap dan sistematis agar suatu proses pembelajaran bisa berjalan dengan interaktif, inspiratif, menyenangkan, menantang (Maryati, 2018), dengan begitu mampu memotivasi peserta didik untuk aktif dalam menggali potensi dirinya sendiri dan menumbuhkan kreativitas, minat, bakat, dan kemandirian dalam belajar yang sesuai dengan perkembangan fisik dan psikologis yang dialami masing-masing peserta didik (Kemdikbud, 2014). Definisi RPP menurut (Ambarawati, 2016) adalah sebagai pegangan bagi pengajar untuk melaksanakan proses pembelajaran di kelas yang memuat Standar Kompetensi/Kompetensi Inti yang menaungi KD, tujuan pembelajaran, materi pembelajaran, metode pembelajaran, langkah-langkah pembelajaran, sumber belajar, dan penilaian.

RPP yang baik sesuai dengan Peraturan Pemerintah No.103 tahun 2014 tentang Pembelajaran pada Pendidikan Dasar, Pendidikan Menengah harus mengacu pada Silabus yang mana ini berbeda dengan Rencana Pelaksanaan Pembelajaran (RPP) pada kurikulum sebelumnya (KTSP), dalam kurikulum 2013 (RPP) harus ada $\mathrm{KI}-1$ hingga $\mathrm{KI}-4$ dengan kegiatan inti yang mengaplikasikan pendekatan saintifik (mengamati, menanya, mengumpulkan data, mengasosiasi, dan mengkomunikasikan). Inti kegiatan dari proses pembelajaran adalah harus meliputi proses eksplorasi, elaborasi, konfirmasi, dan pendekatan saintifik untuk dapat mencapai KI dan KD. Matematika sebagai salah satu mata pelajaran pokok di sekolah dinilai cukup memegang peranan penting, baik pola pikirnya dalam membentuk peserta didik menjadi berkualitas maupun terapannya dalam kehidupan sehari-hari, karena matematika merupakan sarana berpikir untuk mengkaji sesuatu secara logis dan sistematis. Melalui pembelajaran matematika, diharapkan peserta didik memiliki kemampuan berpikir logis, analitis, sistematis, kritis, dan kreatif, serta kemampuan bekerja sama. Berbekal kemampuan tersebut diharapkan peserta didik tumbuh dan berkembang menjadi pribadi yang mampu bertahan hidup pada keadaan yang selalu berubah, tidak pasti, dan kompetitif (Mendiknas, 2006).

Lebih lanjut, dalam Standar Isi untuk Satuan Pendidikan Dasar dan Menengah dijelaskan bahwa matematika merupakan salah satu mata pelajaran pokok yang 
diberikan dengan tujuan agar peserta didik mempunyai kemampuan antara lain memahami konsep matematika, menjelaskan keterkaitan antar konsep, menggunakan penalaran, memecahkan masalah, mengkomunikasikan gagasan, dan memiliki sikap menghargai kegunaan matematika dalam kehidupan, yaitu memiliki rasa ingin tahu, perhatian, dan minat dalam mempelajari matematika, serta sikap ulet dan percaya diri dalam pemecahan masalah.

Dari beberapa tujuan tersebut, tujuan pembelajaran matematika salah satunya adalah adanya kemampuan siswa dalam menjelaskan keterkaitan antar konsep atau yang biasa disebut sebagai kemampuan koneksi matematis.

Dalam kegiatan belajar yang dilaksanakan oleh siswa ada beberapa hal yang dapat mendorong diri mereka, salah satunya adalah minat. Akan lebih baik jika seorang siswa belajar didorong karena minat yang kuat daripada siswa yang belajar tanpa minat sama sekali. Minat tersebut akan timbul dalam diri siswa apabila murid tertarik akan sesuatu karena sesuatu tersebut merupakan kebutuhan yang sangat penting bagi dirinya atau merasa bahwa sesuatu tersebut merupakan hal yang harus dipelajari dan ketika siswa sudah mempelajari, maka akan timbul kebermaknaan dan apa yang dipelajari berguna bagi dirinya.

(Elliot, dkk., 2000) menyatakan "interest is similar and related to curiosity. Interest is an enduring characteristic expressed by a relationship between a person and a particular activity or object", artinya minat serupa dan berhubungan dengan keingintahuan. Minat merupakan karakteristik pokok yang menyatakan hubungan antara seseorang dan objek atau aktivitas tertentu.

Setiap bidang studi memiliki tingkat kesulitan tersendiri dan guru harus mampu membimbing siswa dan menunjukkan hal apa yang harus dicapai siswa agar pembelajaran dapat berjalan dengan baik, contohnya dalam mata pelajaran olahraga siswa dituntut untuk mengembangkan dan meningkatkan batasan kemampuan fisik, karena fisik adalah kunci utama dalam mata pelajaran olahraga. Sedangkan dalam pelajaran matematika siswa dituntut untuk mampu mengembangkan nalar yang baik dan keinginan untuk belajar sendiri dimana kemampuan nalar yang baik dan semangat untuk dapat belajar sendiri sangat membantu siswa dalam menguasai matematika dan membuka potensi dirinya sendiri. (Novitasari, 2016) mengatakan bahwa matematika merupakan disiplin ilmu yang kaya akan konsep yang saling berkaitan satu dengan yang lainnya. Siswa harus mampu menguasai konsep dasar sebelum menguasai konsep-konsep berikutnya (bersifat hierarki), oleh karena itu dibutuhkannya suatu pemahaman yang merupakan modal dasar siswa untuk belajar konsep matematika lebih lanjut (Pirdaus \& Afriansyah, 2016). 
Dengan pemahaman konsep matematika yang baik akan meningkatkan keterampilan pemecahan masalah matematika (Minarni \& Elvis, 2016) dan dengan mengingat tuntutan abad 21 kepada peserta didik nantinya akan semakin saling berkompetensi dan dituntut manusia yang memiliki jiwa problem solver dan pemikir kritis, maka matematika perlu menjadi sarana untuk membentuk pola pikir peserta didik yang berpikir secara kritis dalam menyelesaikan permasalahan. Sehingga Higher Order Thinking Skill (HOTS) yang diharapkan pemerintah dapat terwujud. Berangkat dari banyaknya tuntutan kepada siswa yang harus dipenuhi oleh guru yang salah satunya guru harus mampu memenuhi kelengkapan RPP yang telah ditetapkan oleh kemendikbud. Di era digital saat ini sangat mudah mendapatkan contoh administrasi pengajaran tingkat sekolah yang sudah siap pakai di website. Berbagai situs langsung menyediakan administrasi pengajaran tingkat sekolah lengkap, seperti program tahunan (prota), program semester (prosem), silabus, Rencana Pelaksanaan Pembelajaran (RPP) dan lainnya. Namun, administrasi pengajaran tersebut selayaknya harus dikembangkan dan disesuaikan dengan karakteristik materi, peserta didik serta sarana dan prasarana di masing-masing sekolah.

Salah satu kendala dalam pelaksanaan kurikulum 2013 pada pembelajaran matematika adalah kurangnya pemahaman guru tentang kurikulum 2013 sehingga mempengaruhi pemahaman dalam merancang Rencana Pelaksanaan Pembelajaran (RPP). Rencana merupakan langkah awal yang harus dilakukan dalam setiap kegiatan. Rencana dapat digunakan sebagai pedoman yang berisi ide yang akan dijalankan, tanpa adanya rencana sebuah kegiatan tidak akan berjalan dengan baik. Perencanaan merupakan langkah awal sebelum proses pembelajaran berlangsung (Majid, 2009). Perencanaan pembelajaran memainkan peran penting dalam memandu guru melaksanakan tugas sebagai pendidik dalam melayani kebutuhan belajar siswanya. Tanpa perencanaan yang matang, kegiatan pembelajaran tidak akan sesuai harapan. Menurut Sanjaya (Setiyasih, 2016) RPP merupakan program perencanaan yang disusun sebagai pedoman pelaksanaan pembelajaran untuk setiap kegiatan proses pembelajaran. Perencanaan adalah proses yang sistematis dalam pengambilan keputusan tentang tindakan yang akan dilakukan pada waktu yang akan datang. Menurut Permendikbud Nomor 65 tahun 2013, RPP merupakan rencana kegiatan pembelajaran tatap muka untuk satu pertemuan atau lebih. RPP dikembangkan dari silabus untuk mengarahkan kegiatan pembelajaran peserta didik dalam upaya mencapai Kompetensi Dasar (KD).

Penelitian yang dilakukan oleh (Taufik, 2020) yang berjudul "Analisis Kesesuaian antara Rencana Pelaksanaan Pembelajaran (RPP) dengan Pembelajaran 
yang Diterapkan di Kelas oleh Guru Matematika di MAN 1 Aceh Tamiang" menunjukkan banyak guru yang menjadikan RPP hanya sebagai bahan administrasi yang harus dikumpulkan kepada kepala sekolah bukan sebagai bahan ajar untuk proses pembelajaran, ini menujukkan bahwa masih ada guru yang menganggap remeh tentang pembuatan dan kelengkapan RPP namun ini juga tidak terlepas dari pengaruh zaman yang sudah canggih dimana untuk membuat suatu RPP guru kadang hanya mendownload di internet tanpa memperhatikan kelengkapan RPP tersebut.

Selain itu penelitian lain yang relevan lainnya dilakukan oleh (Fitriani, 2020) yang berjudul "Kesesuaian antara Rencana Pelaksanaan Pembelajaran dengan Pelaksanaan Pembelajaran pada Guru Matematika Kurikulum 2013" Menghasilkan kesimpulan yaitu: 1) kesesuaian antara Rencana Pelaksanaan Pembelajaran dengan kurikulum 2013 di SMA Negeri 11 Makassar pada kelas $X$ yang terdiri dari tiga guru matematika dikategorikan sangat sesuai antara Rencana Pelaksanaan Pembelajaran dengan pelaksanaan proses pembelajaran kurikulum 2013 sebesar 94,44\%, 2) kesesuaian antara pelaksanaan pembelajaran berdasarkan kurikulum 2013 di SMA Negeri 11 Makassar pada kelas X yang terdiri dari tiga guru matematika berada pada kategori sesuai dengan pelaksanaan pembelajaran kurikulum 2013 sebesar $81,68 \%$, 3) kesesuaian antara
Rencana Pelaksanaan Pembelajaran dengan Pelaksanaan pembelajaran berdasarkan kurikulum 2013 di SMA Negeri 11 Makassar pada kelas X yang terdiri dari tiga guru matematika berada pada kategori kurang sesuai antara Rencana Pelaksanaan Pembelajaran dengan pelaksanaan pembelajaran kurikulum 2013 sebesar 62,17\%. Dengan demikian, perlu untuk dilakukan pengembangan instrumen penelitian yang lebih rinci/lebih baik dan mengikuti kurikulum 2013 yang berlaku.

Berdasarkan fenomena ini penulis terdorong dan terinspirasi untuk mengetahui dan menganalisis kelengkapan komponen RPP yang dikembangkan oleh guru SMAN 5 Tapung apakah sudah sesuai dengan tuntutan kurikulum 13 karena begitu pentingnya peran RPP dalam proses pembelajaran siswa apakah hanya dijadikan syarat administrasi saja. Tujuan penelitian ini adalah menganalisis kelengkapan komponen RPP sesuai kurikulum 2013.

\section{Metode}

Penelitian ini dilakukan menggunakan model penelitian deskriptif dengan metode deskriptif analitis menurut (Sugiono: 2009; 29) adalah suatu metode yang berfungsi untuk mendeskripsikan atau memberi gambaran terhadap objek yang diteliti. Penelitian ini dilakukan pada bulan Oktober-November 2020 terhadap tiga orang guru matematika di SMAN 5 Tapung. 
Instrumen penelitian dibuat dalam bentuk angket online dan wawancara online dikarenakan situasi pandemic covid 19. Sasaran dari penelitian ini adalah tiga buah Rencana Pelaksanaan Pembelajaran (RPP) kelas X SMA pada materi persamaan dan pertidaksamaan nilai mutlak.

Analisis pada penelitian ini menggunakan 5 komponen penilaian yang meliputi, 1) Identitas RPP, 2) Perumusan Indikator, 3) Materi Pembelajaran, 4) Kegiatan Pembelajaran, 5) Penilaian, 6) Pemilihan Media Pembelajaran, 7) Pemilihan Bahan Pembelajaran, 8) Pemilihan Sumber Belajar.

\section{Hasil dan Pembahasan}

Berdasarkan analisis terhadap RPP dari tiga orang guru dengan teknik pengambilan data berupa angket, wawancara, dan analisis langsung terhadap RPP maka diperoleh penilaian dalam bentuk persentase, untuk RPP guru ke-1 dan guru ke-2 hasil analisis menunjukkan skor sebesar 79,16\%, ini menunjukkan bahwa RPP yang dibuat telah sesuai dengan peraturan kemdikbud, namun nilai ini hanya terbilang cukup karena salah satu komponen penilaian yaitu pada materi pembelajaran memperoleh skor terrendah sebesar 25\% ini terjadi karena pada semua Rencana Pelaksanaan Pembelajaran (RPP) hanya memuat materi umum namun tidak memuat materi remedial dan pengayaan. Padahal menurut Kemdikbud (2014) dalam lampiran permendikbud nomor 103 tahun
2014 mengatakan bahwa materi pembelajaran bisa diperoleh dari buku teks, buku panduan guru, dan sumber belajar lain seperti muatan lokal, materi kekinian, konteks pembelajaran lingkungan sekitar yang dikelompokkan menjadi materi untuk pembelajaran reguler, pengayaan, dan remedial.

Kemudian untuk penilaian RPP ke-3 diperoleh skor sebesar 73,5\% dengan hasil persentase seperti itu dapat dikatakan bahwa rata-rata Rencana Pelaksanaan Pembelajaran (RPP) yang buat oleh guru SMAN 5 Tapung masuk dalam kategori sesuai dengan kurikulum 2013, tapi dari semua RPP yang ada RPP ke-3 ini memperoleh skor paling kecil meskipun mencukupi syarat ini dikarenakan ada dua komponen penilaian yang memperoleh skor terendah pada komponen penilaian yaitu materi pembelajaran dan pemilihan bahan pembelajaran ini dikarenakan guru hanya terpaku pada bahan pembelajaran di dalam buku paket.

Berdasarkan hasil penelitian mengenai kekurangan RPP hal ini terjadi karena bisa disebabkan beberapa alasan diantaranya:

a. Model pembelajaran yang belum menerapkan pembelajaran aktif yang bermuara pada pengembangan HOTS;

b. Belum memanfaatkan teknologi pembelajaran sesuai dengan konsep dan prinsip tekno-pedagogis/TechnoPedagogical Content Knowledge (TPACK); serta

c. Pada langkah-langkah pembelajaran bagian kegiatan penutup belum 
memuat lengkap kesimpulan, refleksi, penilaian dan tindak lanjut penilaian.

Faktor-faktor kendala dalam membuat RPP serta menerapkan pembelajaran yang sesuai dengan RPP di kelas adalah:

a. Kurangnya motivasi dalam penyusunan RPP sendiri. Pada tiap awal tahun ajaran, guru selalu diminta untuk mempersiapkan administrasi pengajaran termasuk program tahunan, program semester, silabus, RPP hingga soal ulangan. Namun, guru sering hanya menggunakan administrasi pengajaran yang telah ada pada tahun-tahun sebelumnya. Beberapa RPP pada pertemuan tertentu akan diubah nantinya jika akan datang pengawas sekolah.

b. Kurangnya pemahaman cara membuat RPP sesuai dengan kurikulum 2013. Kurikulum 2013 sebagai pengganti Kurikulum Tingkat Satuan Pendidikan (KTSP) sudah mengalami beberapa kali revisi. Ada beberapa hal mendasar yang harus input pada RPP berbasis kurikulum 2013. Salah satunya adalah penggunaan model pembelajaran yang inovatif dan dapat mengembangkan High Order Thinking Skills (HOTs) siswa. Soal - soal latihan yang akan diberikan bukan lagi sekedar soal-soal rutin, namun lebih kepada soal-soal penalaran dan kemampuan pemecahan masalah.

c. Jarangnya pelatihan yang diadakan lembaga atau forum-forum kependidikan. Pelatihan masih dilaksanakan secara bertahap kepada guru-guru bidang studi pada sekolahsekolah. Dinas pendidikan tentunya diharapkan akan konsisten dan berkesinambungan memfasilitasi diskusi dalam implementasi pembelajaran.

\section{Penutup}

Berdasarkan hasil penelitian yang dilakukan melalui analisis dokumentasi RPP SMAN 5 Tapung dapat disimpulkan bahwa kesesuaian kelengkapan komponen RPP kelas $X$ materi persamaan dan pertidaksamaan nilai mutlak yang dibuat oleh guru dan digunakan untuk pembelajaran di SMAN 5 Tapung dikategorikan sesuai kurikulum 2013 dengan persentase sebesar $77,2 \%$.

Saran untuk penelitian selanjutnya agar scope penelitian lebih jauh lagi hingga mencapai daerah- daerah yang kualitas pendidikannya rendah agar mutu pendidikan di Indonesia meningkat secara keseluruhan tidak hanya daerah-daerah besar seperti perkotaan saja dan instrumen penilaian RPP bisa diperbanyak lagi.

\section{Daftar Pustaka}

Afriansyah, E. A. (2017). Desain Lintasan Pembelajaran Pecahan melalui Pendekatan Realistic Mathematics Education. Mosharafa: Jurnal Pendidikan Matematika, 6(3), 463474. 
Afriansyah, E. A., Herman, T., Turmudi, \& Dahlan, J. A. (2021, February). Critical thinking skills in mathematics. In Journal of Physics: Conference Series (Vol. 1778, No. 1, p. 012013). IOP Publishing.

Ambarawati. (2016). Analisis Keterampilan Mengajar Calon Guru Pendidikan Matematika Pada Matakuliah Micro Teaching. Pedagogia: Jurnal Pendidikan, 5(1), 81-90.

Budihardjo, A. H. (2012). Peran LPTK dalam Pengembangan Pendidikan Vokasi Di Indonesia.

Elliot, S. N., Kratochwill, R. T., Cook, L. J., Et.al. (2000). Educational Psychology: Effective Teaching, Effective Learning. New York: The Mc Graw-Hill Companies.

Fitiriani Nur, Fitria dkk. (2020). "Kesesuaian antara Rencana Pelaksanaan Pembelajaran dengan Pelaksanaan Pembelajaran pada Guru Matematika Kurikulum 2013." Jurnal IDAARAH, 4(1), 100-110.

Kunandar. (2014). Penilaian Autentik (Penilaian Hasil Belajar Peserta Didik Berdasarkan Kurikulum 2013). Jakarta: Raja Grafindo Persada.

Majid, A. (2009). Perencanaan Pembelajaran (Mengembangkan Standar Kompetensi Guru). Bandung. Bandung: PT. Remaja Rosdakarya. Maryati, I. (2018). Penerapan Model Pembelajaran Berbasis Proyek dalam Materi Statistika Kelas VIII Sekolah Menengah Pertama. Mosharafa:
Jurnal Pendidikan Matematika, 7(3), 467-476.

Mendiknas. (2006). Peraturan Menteri Pendidikan Nasional RI Nomor 22 Tahun 2006 Tentang Standar Isi Untuk Satuan Pendidikan Dasar Dan Menengah.

Minarni, Elvis, \& Husein. (2016). Mathematical Understanding and Representation Ability of Public Junior High School in North Sumatra. Journal on Mtahematics Education." Journal on Mathematics Education, 7(1), 4546.

Novitasari, D. (2016). Pengaruh Penggunaan Multimedia Interaktif terhadap Kemampuan Pemahaman Konsep Matematis Siswa. FIBONACCI: Jurnal Pendidikan Matematika \& Matematika, 2(2), 8-18.

Nuraeni, R., \& Luritawaty, I. P. (2017). Perbandingan Kemampuan Pemahaman Matematis Siswa antara yang Menggunakan Pembelajaran Inside-Outside_Circle dengan Konvensional. Mosharafa: Jurnal Pendidikan Matematika, 6(3), 441450.

Permendikbud No 103. (2014). Pembelajaran pada Pendidikan Dasar dan Pendidikan Menengah. Jakarta.

Pirdaus, D. A., \& Afriansyah, E. A. (2016). Pembelajaran Kooperatif Tipe Team Assisted Individually Untuk Meningkatkan Kemampuan Pemahaman Matematis Siswa Sekolah 
Menengah Pertama. Jurnal Pendidikan

Matematika RAFA, 2(1), 104-22.

Rahayu, D. V. (2016). Pembelajaran

Dengan Strategi Search-Solve-Create-

Share untuk Melatih Keterampilan

Dasar

Mengajar

Matematika. Mosharafa: Jurnal

Pendidikan Matematika,5(3), 325334.

Setiyasih. (2016). Kesesuaian Rencana

Pelaksanaan Pembelajaran Dengan

Pelaksanaan Pembelajaran Bahasa

Jawa Di Smp Se-Kecamatan Pulosari Kabupaten Malang. Piwulang: Jurnal Pendidikan Bahasa Jawa. Piwulang: Jurnal Pendidikan Bahasa Jawa, 4(1).

Sumartini, T. S., Sunday, R., Madio, S. S., Afriansyah, E. A., Puspitasasri, N., Nuraeni, R., \& Lurytawati, I. P. (2020). Pedagogical

Content

Knowledge. Journal Pekemas, 3(1), 10-

12.

Tarusu, D. T. (2018). Kemampuan pedagogik matematika SD pada mahasiswa PGSD FIP

UNIMA. Mosharafa: Jurnal Pendidikan Matematika, 7(2), 263-272.

Taufik, R. (2020). Analisis Kesesuaian Antara Rencana Pelaksanaan Pembelajaran (RPP) Dengan Pembelajaran Yang Diterapkan Di Kelas Oleh Guru Matematika Di MAN 1 Aceh Tamiang. Pros. SemNas. Peningkatan Mutu Pendidikan 1 (1): 559-63.

Yuniawatika, Y., Yuspriyati, D. N., Sani, I., \& Febriyanti, F. (2016). Perkembangan
Pendidikan Matematika Realistik Indonesia (PMRI) di LPTK Bandung Raya. Mosharafa: Jurnal Pendidikan Matematika, 5(3), 233-246.

\section{Riwayat Hidup PenUlis}

\section{Tomy Abdullah, S.Si.}

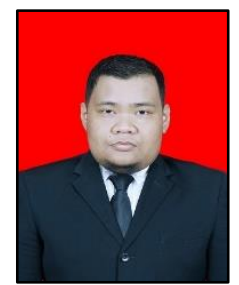

Lahir di Pekanbaru, 13 Agustus 1996. Mahasiswa pendidikan matematika, Pascasarjana, Universitas Riau. Studi S1 FMIPA Matematika Universitas Riau, Pekanbaru, lulus tahun 2019.

\section{Dr. Maimunah, M.Si.}

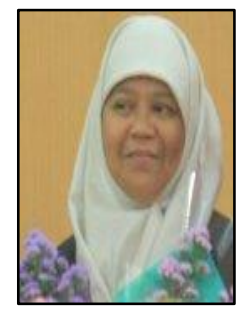

Lahir di Kijang 15 Januari 1962. Jabatan Staf mengajar di Universitas Riau. Menyelesaikan pendidikan Studi S1 Matematika FMIPA IKIP Padang lulus tahun 1986, Studi S2 Matematika FMIPA Universitas Gajah Mada lulus pada tahun 2002 dan Studi S3 Pendidikan Matematika Universitas Negeri Malang lulus pada tahun 2016.

\section{Yenita Roza, Ph.D.}

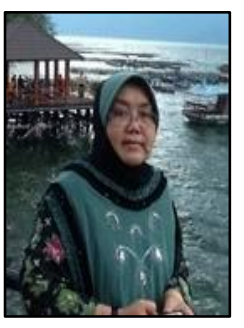

Lahir di Painan 14 Juni 1963. Merupakan Staf mengajar di Universitas Riau. Menyelesaikan Studi S1 Pendidikan Matematika IKIP Padang lulus tahun 1985, S2 EduTech \& ComEdu Universitas of Kentucky (USA) lulus tahun 1990 dan, Studi S3 EduTech \& ComEdu Kansas State University tahun 1994. 